\title{
A Comparison of Higher Education System between China and Ukraine
}

KEYWORDS

higher education, degree system; studying process, China, Ukraine

\begin{abstract}
Shatska Oksana, A Comparison of Higher Education System between China and Ukraine [Porównanie systemu szkolnictwa wyższego w Chinach i na Ukrainie]. Kultura - Społeczeństwo - Edukacja nr 2(6) 2014, Poznań 2014, pp. 9-22, Adam Mickiewicz University Press. ISBN 978-83-232-2869-1. ISSN 2300-0422

This article compares the higher education systems between China and Ukraine, discusses some important peculiarities of the two, and points out the differences between the two. The purpose is to help us get a better understanding of the two countries' higher education systems and to improve the educational exchange and collaboration of the two countries. Special attention is paid to structures of two universities, their facilities, rules of admission, the organization of studying process and some approaches, and levels of acknowledgements by governments which show us the differences and similarities between the two.
\end{abstract}

\section{Introduction}

Education plays an important role in people's life around the world. To receive an education is one of the main goals in everybody's life. Many countries are doing everything to improve and raise the levels of their higher education systems in order to attract people just to study in their countries.

In recent years, because of the increasing role of higher education, China's economy has developed very fast and its social progresses are known throughout the world. Since 1978, the Chinese government has adopted the Open and Reform Policy. According to Deng Xiaoping's theory, one of the goals of Chinese education is geared to the need of modernization, of the world and of the future (Li Lanqing, 2004). 
After that, China has started to internationalize its higher education with more power. For example, China signed agreements on mutual recognition of academic degrees with Ukraine in 1998 (Ministry of Education of the People's Republic of China). Today a lot of Ukrainian people are interested in Chinese cultures, traditions, and the ways of cooking. Even pupils study Chinese as foreign language at school. To learn eastern languages, esp. Chinese is now very popular in Ukraine. Ukrainian people always admire Chinese wisdom. That's why we choose this topic for researching.

This paper states the history of Chinese higher education, its stages of development which led to modernization and improvement of educational system. Here we can see the changes of university structure during different periods in China. The paper also points out the possibility of receiving higher education in China and Ukraine by taking two universities - Shanxi Normal University in China and Luhansk Taras Shevchenko National Pedagogical University in Ukraine as an example. Structures of the universities, their facilities, rules of admission, the organization of studying process and some approaches, and levels of acknowledgements by governments show us the differences and similarities between the two.

The purpose of this paper is to analyze the peculiarities which are connected with different traditions, cultures, and opinions in the two countries, with the hope of increasing and improving the educational exchange and collaboration between the two countries.

\section{Stages of China's Higher Education}

Chinese higher education has experienced three periods of development in history:

- education before the Cultural Revolution (1949-1966);

- education during the Great Proletarian Cultural Revolution period (1966-1976);

- education in the Post-Mao Zedong period (1976- till now).

During the first period, Chinese higher education had a schooling period of 5 years. Some universities had postgraduate research and training. In 1950s Chinese universities took the Soviet Union model of higher education. The number of universities decreased and specialized in different fields (major disciplines were very narrow and particularized), because of the restructuring higher education. 
During the second period, the schooling period of Chinese higher education was shortened to 2 or 3 years. Some universities had postgraduate programs which were like in-service training. Political power controlled everything at that time. From the late 1950s to the mid-1960s, China had a mixed Confucian-Western style higher education because of the political reasons. The Cultural Revolution stopped the blossoming of higher education. Until 1977 the National Entrance Examination was finally resumed.

Since 1977, the Chinese government started to inform its educational system and changed its university entrance system from recommendation to examination. During that time higher education was highly valued by Chinese government, because of the desire to develop China and to bring it to a high position in the world. There were 4-year undergraduate and 3-year postgraduate programs in universities. During that period, many Chinese students went to study abroad in such countries as the Soviet Union, the United States, Japan and Western Europe.

During the late 1980s and the early 1990s, Chinese government began to expanse its higher education and increases the enrollment of college students. From 1993 to now education continues to advance. Since 1999, more and more students have entered universities. In 2002 there were altogether 16 million students in different types of higher education institutions.

Education for 1,3 billion Chinese people is really important and also the main issue in China. Chinese government tries to help everybody to have a good education, to work and to be successful. Now the number of university students in China is the largest in the world. Ten years of reform has created a new Chinese high education system (Li Lanqing, 2004; Kurian, 1998).

\section{The Mode of Educational Administration in China}

According to China's present educational system, there are universities, institutions of higher learning specialized in one subject - colleges, institutes. The educational administration consists of 4 levels:

- the Ministry of Education;

- the Departments of Education in provinces, autonomous regions and 4 municipalities (Beijing, Shanghai, Tianjin and Chongqing);

- Education Bureaus in large cities;

- Education Bureaus in counties. 
The different administrations of education follow the national educational polices and plans. All the universities, both state-owned and private-owned, are under the control of the Ministry of Education (Kurian, 1998).

\section{The National University Entrance Examination in China}

In the past, academic qualifications from school, social background, family reputation played very important role in the admission to university. Since 1952, the National University Entrance Examination was set in China, but during the Great Cultural Revolution it was canceled.

In 1977 the Ministry of Education returned the National University Entrance Examination to normal. Everyone under the age of 35 had the opportunity to enter university after passing the examinations. The basic subjects of the university entrance examination were Chinese, Mathematics, Politics, History, Geography, English, Physics, and Chemistry. Now there are 3 compulsory subjects for high school students to take in the National University Entrance Examination - Chinese, English, Mathematics and one extra subject (Kurian, 1998).

Here we examine the peculiarities of Chinese and Ukrainian higher education developments at present days by comparing Shanxi Normal University in China and Luhansk Taras Shevchenko National Pedagogical University in Ukraine.

\section{Luhansk Taras Shevchenko National Pedagogical University in Ukraine}

The history of Ukrainian education is connected with the whole history of Ukrainian people. In 1632 the first university named Kiev-Mogilyansky College appeared where only children from rich families could study. Nowadays there are a lot of universities in Ukraine. Young people can choose any one for receiving education.

March 1, 1921 Luhansk Taras Shevchenko National University (LNPU) was established and the first pedagogical courses were opened there. Two years later the first higher education institution was founded on the basis of these courses in Donets Basin. In 1924 this institution was renamed as Luhansk State Pedagogical University and then named after famous Ukrainian writer - Taras Shevchenko.

Today LNPU is one of the most popular, powerful and prestigious universities in Ukraine. A lot of famous people (writers, journalists, sportsmen, teachers, sin- 
gers, businessmen) graduated from this university. It has IV level of accreditation. For more than 80 years, it has been very successful in educational field. The president of the university is a professor with a Doctor degree of pedagogical sciences, and a member-correspondent of Academy of Pedagogical Science, V.S. Kurilo.

Now the university has more than 26, 000 students from different parts of Ukraine and other countries such as: Russia, China, and Turkey, etc.

The University always takes part in different international and Ukrainian competitions. For example, in 2000 LNPU was admitted as the best sport educational institution for getting two silver and bronze medals at 27 Olympic Games in Sydney; according to the results of VII international level LNPU received two nominations: "the Best Regional University in Ukraine" and "For a Big Contribution to Ukrainian Development of Education".

In 2006-2007 German language center of Goethe Institute and Institute of Confucius were established in LNPU. Students can also receive Diploma of American Higher Education Institute (Franklin Pierce College) in Luhansk, which is acknowledged in the USA and Europe. There are special Master's programs in Business Administration.

There are two academic journals - "Visnik LNPU”, "Osvita Donbassu”, where teachers and students can publish their research papers.

Nowadays LNPU is the only Ukrainian university which has passed international evaluation. It has a lot of partners among educational institutions around the world: such as China, Austria, Latvia, Netherlands, Russia, the US, France, Japan etc. Undergraduates, post-graduates and teachers of LNPU have probation periods to practice in these countries. They can take part in international programs to study abroad for several terms. Centers of Ukrainian education, science and culture have been established in several Chinese educational institutions (Luhansk Taras Shevchenko National University, Educational portal).

Today the university is a big education research and industrial complex which has following subdivisions:

Institutes:

- Institute of Economics and Business;

- Institute of Information Technologies;

- Institute of Tourism and Technology of Population Service;

- Institute of Culture and Art;

- Institute of Continuing Education;

- Institute of Physical Education and Sports. 
Faculties:

- the Faculty of Foreign Languages;

- the Faculty of Natural Science;

- the Faculty of History;

- the Faculty of Psychology and Pedagogy;

- the Faculty of Ukrainian Philology;

- the Faculty of Preparatory Training.

Departments:

- Department of Statistics, Quality Monitoring and Curriculum Development;

- Personal Department;

- Department for Research;

- Accountant Department;

- Editorial-publication Department;

- Centre of Informative Technologies;

- Accreditation and Licensing Department;

- International Department.

There are colleges, lyceums in Stakhanov, Lisichansk, Bryanka, Rubizhne, which belong to the university's complex. There are 115 specializations in the universities, such as pre-school education and therapeutic pedagogy, primary school education, professional education, labor studies and basics of business undertaking, social pedagogy, physical rehabilitation, culture studies, and translation etc. (Luhansk Taras Shevchenko National University).

Applicants should first prepare some documents to the Admission Committee in LNPU, pass examinations (tests) to be a freshman. They can take two-weeks preparatory courses which may help to improve their skills and knowledge.

At the university you can receive such qualifications: Junior specialist, Bachelor, Specialist, Master. Graduates get diplomas of state standard. In Ukraine there is also one more degree - Candidate of Science - between a Master's and a Doctor's degree.

The university has Ph.D./Candidate of Science degree in such specialties:

- Ukrainian Literature;

- Ukrainian Language;

- Pedagogy and History of Pedagogy;

- Social Pedagogy;

- Russian Language;

- World History. 
As for Doctor's Degree of Science there are 30 specializations, e.g. Mathematical Analysis, Human and Animals Physiology etc.

If you want to be a Candidate, you should have a Master's degree. Postgraduate students must study for 3 years as full-time students and 4 years as parttime students. During this period they have to pass 3 candidate examinations (philosophy, foreign language, and one examination of specialization), write dissertation and more than 5 articles, and take part in different conferences and seminars. After all these comes this dissertation defense.

Mutual exchanges and cooperation lead to new development and possibilities. That's why a lot of universities have contacts with each other. Every year LNPU signs some agreements with foreign educational institutions and research organizations of the Commonwealth of Independent States (Luhansk region state administration, Youth informational portal).

\section{Shanxi Normal University in China}

In 2005 SXNU was rated as the 16th best Teachers Universities among 228 ones in China. In Shanxi Province, Shanxi Normal University is the most important educational institution for training future high school teachers. It is one of the 5 universities with the longest history in Shanxi. Situated in Linfen in the south of Shanxi, SXNU was established in 1958 and named as Jinnan Teachers Junior College. In 1962 the system of higher education in Shanxi was changed and only one junior college was left in the whole province. Two years later it was merged with the Shanxi Teachers College (now Shanxi University) and the schooling period was changed from three years to four years. In 1984 it was renamed as Shanxi Normal University by the Ministry of Education. In 1999 Linfen Physical Education College and Shanxi Normal Junior School of Vocational Education merged into Shanxi Normal University.

During the Cultural Revolution, Shanxi Teacher's University suffered a great loss: teaching was stopped for 6 years; the university moved to the western part of Linfen. In 1977, SXNU returned to normal and started a new development period again.

Now there are total 28 schools or colleges (faculties) in this university:

Schools and Research Institutes:

- School of Economics; 
- School of History and Tourism Culture;

- School of Politics and Law;

- School of Foreign Languages;

- Research Institute of Economics;

- Research Institute of Shanxi Culture;

- Research Institute of Marxist Theory and Moral Education;

- Research Institute of Sociology;

- School of Education and Psychology;

- School of Fine Arts;

- Mathematics Weekly, University Press;

- School of Life Sciences;

- Research Institute of Biological Diversity;

- School of Information Engineering and Physics;

- School of City and Environmental Sciences;

- Research Institute of Modern Physics;

- Research Institute of Regional Economics;

- School of Chinese Language and Literature;

- School of Mathematics and Computer Science;

- School of Educational Technology;

- Research Institute of Chinese Opera and Relics;

- Research Institute of Yellow River Folklore;

- Research Institute of Editing and Publishing;

- Research Institute of Curriculum and Teaching;

- University Library;

- School of Continuing Education;

- School of Professional Technology Training;

- School of Biological Technology and Engineering;

- School of Physical Education.

There are also non-degree programs, night school, correspondent courses, the experimental middle school, an experimental primary school and a kindergarten.

About 12,488 students, 16,215 adult students, and over 300 postgraduate students are studying at this university. There are about 1000 full-time instructors, 138 full-professors, 420 associate- professors and 392 lectures.

SXNU has good equipment and facilities for successful teaching and studying: the Media Center, Computer Center, 11 language labs, electronic library, a foreign language broadcasting station. 
The University has following journals and periodicals: Chinese Language Coach; Journal of Shanxi Normal University (Social Sciences) and English Weekly.

There are 4 academic years for undergraduate education. Students receive diplomas after graduation. This diploma is different from the B.A. degree certificate. 4-year students will have a B.A. degree with the diploma. 3-year programs (subdegree programs) don't lead to any degree. Students who have failed in many courses (usually 7) cannot be granted any graduation certificates.

As for the schooling periods: they have 3 years for M.A. and another 3 years for Ph.D. In the past, Applicants should be under the age of 35 . But now any age is allowed. For M.A. degree, students must study Marxist theory, take theoretical and specialized courses, write some term thesis and MS thesis, and take the dissertation defense.

Ph.D. could be received by candidates who take entrance examination include two professional courses and one foreign language. Doctoral programs generally take 3 years for students with a Master's degree. After passing all the courses (compulsory, selective) they have a dissertation defense.

SXNU has exchange relations with several foreign colleges and universities such as Austin Peay State University in Tennessee, Dalarna university in Sweden, Bridgewater State College in Massachusetts, Brooklyn State University in New York; the Gantokakuen University in Japan etc. (Education in China, Shanxi Normal University).

\section{Process of studying in both countries}

In China, there are 2 semesters - spring and fall semesters. Students have classes 5 days a week. The teaching language is Putonghua. In several minority areas the local minority language is used and taught. Students have only end-term examinations every semester. The Ministry of Education set a standard curriculum, but list of courses for each grade is decided by each university. Students must take the examinations of the courses they take at the end of each term. The grading system is from 0 to 100.60 is the lowest passing mark. Teachers write the scores on the sheets and give them to the department, where the secretary puts the scores in folders in the computer. Every student has their own log number. They can see their results on the campus web-site of the university. It is like an electronic score book.

There are 2 terms with 2 vocational holidays (winter and summer) in Ukraine. Students have class 5 days a week, sometimes 6 days. The teaching languages are 
Ukrainian and Russian. At the end of each term there are several examinations. Students should reach a certain level according to every subject. Teachers fulfill the test books and the sheets. Test books are students' books, where teachers write marks of passing exams, subjects, hours, dates, their names and signs. If a student has a certain score, he will not take the examination. It is like automatically passing. Students should keep these books until graduation. The marks from test books will be in supplements of future diplomas.

In China the lessons start at 8.00 and end at 18.00 with a 2-hour lunch break (from 12.00 till 14.00). After supper, students may go to the library or stay in classrooms to continue studying till 22:00. Some students stay in the university to study or to do some part-time jobs during summer vocation. In Ukraine the lessons begin at 8.30 and end at 14.00, if students have a day-scheduled study period; or from 14:00 till 19:00, if they have an evening period. Students can be at university till 20.00, and then the doors are closed. After getting back home, students may continue studying.

In China, most of the students live in dormitories (hostels) which are on the campus of the university. The buildings of the dormitories are divided in men's and women's separately. 6-8 students share a room. The university has dininghalls where students have their meals 3 times a day. In Ukraine there is no strict division among hostels. Boys and girls live in the same building, but in separate rooms. 2-4 students share one room.

As for students' documents: in Ukraine there are test book; the reading card; student's card and dormitory card. In China the students have only student's cards and reading cards.

In both countries there are full-time and part-time students. Full-time students have classes the whole day. Part-time students go to work and have classes according to the time-table. In Ukraine, part-time students study for longer period than full-time students.

In most Chinese universities, there are class advisers (or head teachers) who are busy with students' affairs. They help everyone to solve any kinds of problems.

\section{Scholarship in China and Ukraine}

There are several kinds of scholarships which are set up by the Chinese Scholarship Council (CSC):

- the undergraduate student scholarship; 
- the postgraduate student scholarship;

- the doctoral student scholarship;

- the learners for Chinese language scholarship;

- the Visiting Students scholarship;

- the Senior Visiting Students scholarship;

- the Great Wall Scholarship;

- the excellent student scholarship;

- HSK Winner scholarship etc.

Scholarship for undergraduates is granted to applicants under 25 years old, who finished senior high school with excellent scores, passed the entrance examination (NUEE), and study for receiving Bachelor's degree.

Scholarship for the Master's degree students is granted to applicants under 35 years old, who had Bachelor's degree and excellent marks. Students should have 2 recommendation letters from professors or associate professors.

Scholarship for a Ph.D. student is granted to those who study at a university, who are below 40 years old, should have recommendation from 2 professors or associate professors, and had Master's degree and excellent score.

Scholarship for Chinese language students is provided for non-Chinese students below 35 years old who study Chinese during 1 or 2 school years.

Scholarship for the Visiting students is for those who study their major in China and are below 45 .

Scholarship for Senior Visiting students are for those who do further study on certain subjects with a Chinese supervisor. They should be below 50 years old and are recommended by 2 professors or associate professors.

The Great Wall scholarship is open to the United Nations Educational Scientific and Cultural Organization (UNESCO) for Visiting students and Senior Visiting students

Scholarship for excellent students is for those who study for a Master's or a Ph.D., who are diligent and have good academic records.

HSK Winner scholarship is for overseas students who are studying for more than 1 year and are below 40 and have passed Chinese Proficiency Test (China Scholarship Council).

There are also several kinds of scholarships in China's universities which are set:

- the comprehensive scholarship (it depends on results of the exams and daily behavior);

- the learning scholarship (it depends on the results of the exams); 
- the behavior scholarship (it depends on the daily behavior through the two terms).

Every scholarship has 3 levels, of which each includes different amount. Most students can have a scholarship every year, but all of them have to pay tuition.

In Ukraine, we have different situation. Students who pass the entrance examination with high score don't need to pay for education and can receive a scholarship every month. The amounts of the scholarship depend on their scores and results of education. Students who pay for education cannot have scholarship at all. The best students can have President's scholarship ${ }^{1}$.

\section{Conclusion}

Higher education is a very important topic in both China and Ukraine. China has created its own new model of higher education during its stages of development. During those periods the forms of studying were changed according to the government's policies. The Great Cultural Revolution ruined the growth of higher education for 10 years, but later everything got on the right track by several educational reforms and new approaches. Since the Open and Reform Policy, China has established foreign relations with many countries, which helps to find new methods to build a new education for a new generation. Nowadays China and Ukraine have developed exchange programs of students and teachers between their universities. It brings new advantages for the higher education development of the two countries.

We here compared the 2 universities - Shanxi Normal University in China and Luhansk Taras Shevchenko National Pedagogical University in Ukraine - for research, because both of them are teachers' universities. Teachers play a crucial role in education and social development. They can help to create a new society with new views and desires. Both universities are prestigious in their countries. They contribute new things and waves to higher education development. Both universities take part in different competitions to pass international evaluation.

The main purpose of this paper is to introduce the general structures of Chinese and Ukrainian higher educational systems so as to help us have a better understanding of each other's educational process and improve the higher education

\footnotetext{
${ }^{1}$ Thesis for a Candidate degree, speciality 13.00.01. - General pedagogy and history of pedagogy. - State institution: Luhansk National University named after Taras Shevchenko; Luhansk, 2012.
} 
systems of the two countries. Finally, for the reasons of time and personal experience, this study is only an initiative attempt and has many disadvantages. In the future we will continue our further research in this area for new development of the two countries (Shatska).

\section{Literatura}

Kurian G. T. (1998). World Education Encyclopedia. New York.

Li Lanqing. (2004). Education for 1,3 Billion. Beijing.

Shatska O.P. (2012). The Development of Higher Teacher's Education in China (70-th of XX - the Beginning of XXI Century). - Manuscript. Thesis for a Candidate degree, speciality 13.00.01. General pedagogy and history of pedagogy. State institution: Luhansk National University named after Taras Shevchenko.

\section{Źródła internetowe:}

Youth informational portal (irtafax news); www.prostranstvo.ru/news/news/show/1154434823.html China Scholarship Council; www.csc.edu/cn

Education in China; www.famouschinese.com/virtual/Education_in_China/

Educational portal; www.osvita.org.ua/highedu/?hes_id=707

Luhansk region state administration; http://loga.gov.ua/oda/press/archive/archive_6685.html? template $=33$

Luhansk Taras Shevchenko National University; www.lnpu.edu.ua

Ministry of Education of the People's Republic of China; www.moe.edu.cn/

Shanxi Normal University; www.sxnu.cn/english/introductiontoshidal.html

Shanxi Normal University; www.sxtu.edu.cn/english/

\section{Porównanie systemu szkolnictwa wyższego w Chinach i na Ukrainie}

\section{Streszczenie}

Celem niniejszego artykułu jest porównanie systemów szkolnictwa wyższego na Ukrainie i w Chinach ze wskazaniem na różnice i podobieństwa. Przybliżenie funkcjonowania tych dwóch systemów pozwoli na lepsze ich rozumienie oraz możliwość podjęcia współpracy. W celu analizy postawionego problemu badawczego autorka pracy wybrała dwa uniwersytety: Shanxi Normal University w Chinach oraz Luhansk Taras Shevchenko National Pedagogical University na Ukrainie. Porównała ich strukturę organizacyjną, zasady rekrutacji, organizację studiów, a także prowadzoną przez państwo politykę wobec uczelni wyższych. 
W pierwszej części pracy autorka przybliża nam przemiany zachodzące w chińskim szkolnictwie wyższym, a także wskazuje na wzrost zainteresowania kulturą chińską ze strony Ukrainy i jej mieszkańców. Prezentuje rozwój i przemiany szkolnictwa wyższego w Chinach od 1949 roku do dnia dzisiejszego. W dalszej części omówiona zostaje struktura szkolnictwa wyższego w Chinach.

W drugiej części pracy autorka prezentuje selekcyjną funkcję szkolnictwa wyższego w Chinach z uwzględnieniem znaczących przemian - od modelu selekcyjnego, opartego na pochodzeniu społecznym, do modelu opartego na egzaminach wstępnych. W dalszej części omówiona zostaje struktura i społeczne znaczenie Luhansk Taras Shevchenko National Pedagogical University na Ukrainie. Przedstawiona zostaje również współpraca międzynarodowa prowadzona przez uczelnię, a także jej działalność naukowo-badawcza.

Następnie autorka pracy prezentuje strukturę i działalność Shanxi Normal University jako jednej z najlepszych uczelni pedagogicznych w Chinach. Przywołuje dane statystyczne, z których wynika, iż na uniwersytecie tym na różnych poziomach kształcenia studiuje prawie 30000 studentów. Omawia również ścieżki kształcenia na poziomie studiów licencjackich, magisterskich oraz doktoranckich.

Autorka prezentuje także organizację studiów, podejmując próbę porównania modeli obowiązujących w Chinach i na Ukrainie. Wskazuje, iż obowiązującym językiem nauczania na chińskich uczelniach jest standardowy język mandaryński (Putonghua), jednak w obszarach zamieszkiwanych przez mniejszości dopuszcza się nauczanie w językach lokalnych. Z kolei, jak dowiadujemy się z artykułu, na ukraińskich uczelniach językami wykładowymi są rosyjski i ukraiński. Okazuje się też, iż na Ukrainie nadal obowiązują indeksy, podczas gdy w Chinach osiągnięcia studentów zamieszczane są w systemie komputerowym. Autorka opisuje również funkcjonowanie domów studenckich na Ukrainie i w Chinach. W ostatniej części artykułu natomiast przybliża czytelnikowi mechanizmy przyznawania stypendiów naukowych. W konkluzjach autorka wskazuje na potrzebę prowadzenia dalszych komparatystycznych badań dwóch przywołanych systemów. 